\title{
Agenda Good Governance dan Globalisasi Ekonomi: Suatu Tinjauan Kritis
}

\section{Budi Winarno}

Jurusan Hubungan Internasional, Fakultas IImu Sosial dan IImu Politik, Universitas Gadjah Mada Bulaksumur, Yogyakarta, 55281

Email:winarno@ugm.ac.id

\begin{abstract}
As a concept, development and good governance are not neutral, but they bring domination and interest. Currently, in era of globalization, there is a trend that shows democratization and the agenda of good governance are suspected to become a neoliberal project aimed to strengthen the domination of market over the state. Therefore, in order to prevent the agenda of good governance serving the interest of global corporations, democracy should be able to guarantee the individual rights, and the government continuously plays its crucial role in pushing the realization of social justice. In the context of maintaining democracy and civil society, the agenda of good governance are not only implemented by public institutions, but also they are done by both global corporations and global governance institutions. Key words: development, democratization, good governance, and economic globalization.
\end{abstract}

\begin{abstract}
Abstrak
Sebagai sebuah konsep, pembangunan dan pemerintahan yang baik tidak netral, tapi syarat dengan dominasi dan kepentingan. Di era globalisasi saat ini, ada kecenderungan bahwa demokratisasi dan agenda pemerintahan yang baik diduga menjadi proyek neoliberal yang bertujuan untuk memperkuat dominasi pasar atas negara. Oleh karena itu, untuk mencegah agenda pemerintahan yang baik melayani kepentingan korporasi global, demokrasi harus mampu menjamin hak-hak individu, dan pemerintah terus memainkan peran penting dalam mendorong terwujudnya keadilan sosial. Dalam rangka menjaga demokrasi dan masyarakat sipil, agenda pemerintahan yang baik tidak hanya dilaksanakan oleh lembaga-lembaga publik, tetapi juga dilaksanakan oleh perusahaan global dan lembaga-lembaga pemerintahan global.

Kata Kunci: pembangunan, demokratisasi, pemerintahan yang baik, dan globalisasi ekonomi.
\end{abstract}

\section{PENDAHULUAN}

Rita Abrahamsen (2000), melalui studi yang dilakukan di negara-negara Sub-Sahara Afrika, menegaskan bahwa konsep good governance, yang dalam konteks Afrika diperkenalkan pertama kali melalui laporan Bank Dunia (1989) dengan judul Sub-Saharan Africa: From Crisis to Sustainable Growth, hendaklah dilihat secara kritis dan hati-hati. Dari hasil studi yang kemudian dibukukan dengan judul Disciplining Democracy: Development Discourse and Good Governance in Africa, ia menegaskan bahwa munculnya konsep good governance tidak dapat dilepaskan dari sejarah kemunculan dan kegagalan teori-teori pembangunan.
Dengan mengutip Gilbert Rise (1997), Abrahamsen menyatakan bahwa kekuatan wacana pembangunan muncul dari kemampuannya untuk merayu, membujuk, menarik, membentuk mimpi, dan juga merusak, memalingkan dari kebenaran, dan menipu. Selanjutnya, ia menyatakan bahwa janji untuk menghapus kemiskinan begitu menggoda hingga meski sejarah penuh dengan kegagalan, kepercayaan pada pembangunan tetap ada. Menurut Abrahamsen, kegagalan masa lampau memunculkan teori-teori baru, setiap teori mengklaim telah menemukan pemecahan yang sesungguhnya atas persoalan pembangunan. 
Dalam konteks ini, agenda good governance hanyalah teori terakhir dari serial panjang teori-teori tersebut, reproduksi terakhir dari mimpi tersebut (Abrahamsen, 2000: 80).

Jika dikaitkan dengan konteks Indonesia saat ini, maka studi Abrahamsen ini menarik untuk ditelaah lebih lanjut. Pertama, hampir mirip dengan negaranegara Dunia Ketiga lainnya, sejarah pembangunan di Indonesia juga banyak menyisakan kegagalan. Tidak seperti 'dikhotbahkan' oleh para pendukung developmentalisme, dalam konteks Indonesia, pembangunan pada dasarnya gagal meraih tujuan yang diinginkan, yakni masyarakat yang maju dan berkeadilan sosial-ekonomi. Sebaliknya, ekses pembangunan dalam bentuk pemiskinan dan ketimpangan dalam distribusi pendapatan menjadi persoalan yang jauh lebih mengemuka. Kedua, lebih dari kegagalan-kegagalan di atas, pembangunan yang dilakukan selama lebih kurang 30 tahun telah meninggalkan utang yang tidak sedikit jumlahnya. Hingga Juli 1999, utang Indonesia kurang lebih 150 milyar dollar AS. Suatu jumlah yang mencatat rekor utang terbesar diantara negara pengutang terberat dunia. Berkaitan dengan hal ini, Indonesia sudah dapat dikatakan sebagai kelompok "negara-negara miskin pengutang berat (Highly Indebted Poor Countries)" (Sritua Arief, 1999: 6-7). Akibatnya, ekonomi Indonesia menjadi sangat tergantung kepada kekuatan asing, dan APBN dibebani oleh kewajiban membayar utang yang sangat memberatkan. Ketiga, di bidang politik, kegagalan juga nampak dari ketiadaan pembangunan sistem politik demokratis. Sebaliknya, pembangunan selama lebih kurang tiga dekade telah memberi peluang bagi konsolidasi sistem politik otoriter yang menindas. Akhirnya, kegagalan-kegagalan ini berkaitan erat dengan krisis ekonomi yang terjadi pada pertengahan tahun 1997 telah memancing gerakan massa yang berimbas pada kejatuhan rejim Orde Baru pada pertengahan tahun 1998.

Selanjutnya, kejatuhan rejim yang dikenal korup dan menindas tersebut, telah membuka peluang bagi terjadinya perubahan-perubahan dalam sistem politik dan penyelenggaraan pemerintahan secara besar- besaran, dan bahkan mungkin radikal. Pers menjadi semakin bebas, partai politik tumbuh subur selama masa reformasi sebagai akibat diperlakukannya sistem multipartai, presiden dipilih secara langsung, dan yang lebih penting diberlakukannya desentralisasi dan otonomi daerah berdasarkan UU No. 22 Tahun 1999 dan UU No. 25 Tahun 1999. Dalam konteks inilah, agenda good governance menempati posisi sentral dalam diskusi-diskusi publik

Oleh karena itu, suatu tinjauan kritis terhadap wacana ini adalah penting karena seperti ditunjukkan oleh Abrahamsen bahwa wacana good governance bukan merupakan konsep yang netral, tetapi memuat relasi kuasa tertentu. Bahasa juga merupakan suatu medium dominasi dan kekuasaan (language is also a medium of domination and power) (Latif dan Ibrahim, 1996: 15), dan wacana baru pembangunan tidak hanya disampaikan oleh, tetapi juga berfungsi memelihara dan mereproduksi bentuk-bentuk kekuasaan dan kebijakan tertentu dalam tata dunia baru (Abrahamsen, 2000: 48). Akhir Perang Dingin membuat agenda good governance lebih konsisten untuk dipraktikkan, tetapi ini bukanlah merupakan ekspresi altruisme murni ataupun idealisme. Lebih dari itu, ia hanya merupakan transformasi diskursif dan secara historis tergantung dan menjadikan Barat tetap mampu memelihara hegemoninya atas negara-negara Dunia Ketiga (Abrahamsen, 2000: 78).

Sama halnya dengan kemunculan konsep pembangunan di era tahun 1960-an yang bias kepentingan Barat atau tepatnya Amerika Serikat (AS), kemunculan konsep good governance ini juga tidak bisa dilepaskan dari maksud-maksud tersebut. Sebagai contoh, proyek pembangunan yang diprakarsai oleh AS pada tahun 1960-an, setidaknya dilatarbelakangi oleh dua hal (Abrahamsen, 2000; Muhadi Sugiono, 1999). Pertama, pembangunan di negara-negara Dunia Ketiga yang diprakarsai oleh AS merupakan usaha antisipatif terhadap perluasan komunisme. Menurut cara pandang Barat (khususnya AS), kemiskinan merupakan lahan subur bagi tumbuh dan berkembangnya komunisme. Oleh karena itu, pembangunan dilakukan sebagai usaha untuk 
menjawab kekhawatiran tersebut. Kedua, persoalan instabilitas dunia. Pada dasarnya, ini merupakan cara pandang yang berbau rasis dalam melihat persoalan negara-negara Dunia Ketiga di mana kemiskinan dilihat sebagai situasi yang potensial dalam mendestabilisasi dunia. Oleh karenanya, pembangunan negara-negara miskin wajib dilakukan sebagai usaha untuk memelihara stabilitas dunia (khususnya Barat) yang telah mapan.

Atas alasan-alasan inilah, tulisan dalam artikel ini ditujukan untuk melihat kembali secara kritis agenda good governance terutama dalam konteks globalisasi dan liberalisasi ekonomi. Namun, untuk menghindari pengulangan dari apa yang telah disampaikan oleh Abrahamsen, tulisan ini lebih difokuskan untuk menyingkap secara kritis agenda good governance itu sendiri dalam konteks globalisasi ekonomi. Secara spesifik, tulisan ini ditujukan untuk membahas berbagai persoalan menyangkut makna dan konteks kemunculan agenda good governance serta implikasinya dalam penyelenggaraan birokrasi publik. Akhirnya, tulisan ini akan ditutup dengan beberapa catatan kritis menyangkut implementasi good governance di Indonesia. Suatu rekomendasi tindakan adalah perlu dalam rangka tetap memelihara sistem pemerintahan demokratis dan menjamin hak ekonomi, sosial, dan politik warga negara.

\section{PEMBAHASAN}

\section{APA ITU GOOD GOVERNANCE?}

Uraian dalam tulisan ini akan diawali dengan usahausaha untuk mencari pemahaman konseptual menyangkut makna good governance dan konteks kemunculan konsep tersebut. Hal ini dilakukan karena suatu kajian kritis konstruktif tidak akan pernah bisa dilakukan jika makna dan maksud dari teori atau konsep yang hendak dikaji tersebut belum dipahami secara baik. Oleh karenanya, suatu tinjauan teoritik tidak saja penting, tetapi juga berguna untuk menyingkap konteks kemunculannya sehingga dapat dicari muatan kepentingan yang berada di balik konsep atau teori tersebut. Asumsinya, tidak ada satupun teori atau konsep yang diformulasikan dalam ruang hampa. Sebaliknya, ia merupakan interaksi dari berbagai aktor sosial, dalam suatu peristiwa yang kompleks, dan tentunya melibatkan interpretasi subyektif sang aktor. Oleh karenanya, bias kepentingan hampir pasti tidak dapat dihindarkan. Sebagai contoh, munculnya gagasan neoliberal yang diprakarasai oleh Milton Friedman dan Friedrich Hayek, yang mendominasi kehidupan sosial, ekonomi, dan politik dewasa ini di mana pasar diberi tempat terhormat, sedangkan negara hampir sama sekali dimarginalkan hendaknya dilihat dalam kaitannya dengan kegagalan kebijakan ekonomi Keynesian waktu itu. Selama beberapa dekade, kebijakan ekonomi Keynesian ini berhasil dalam memacu pertumbuhan ekonomi, tetapi akhirnya terpuruk karena ketidakmampuannya mengatasi penyakit hiperinflasi. Selanjutnya, peristiwa ini dijadikan momentum oleh para pemikir neoliberal atau kelompok Kanan Baru (the New Right) untuk menyerang fondasi ekonomi Keynesian dengan menyatakan bahwa kegagalan ekonomi Keynesian adalah karena negara terlalu intervensif. Untuk mengatasi hal ini, cara yang paling efektif adalah bagaimana mengeluarkan negara dari aktivitas ekonomi dan menyerahkannya kepada mekanisme pasar. Namun lebih dari itu, gagasan para pemikir neoliberal, yang oleh Gramsci disebut sebagai intelektual organik ${ }^{1}$ ini, juga mengabdi kepada kepentingan tertentu (Sugiono, 1999: 43). Setidaknya, ia merepresentasikan kelas sosial ekonomi yang mereka wakili.

Kembali ke konsep good governance, pertama kali konsep ini dipublikasikan oleh Bank Dunia pada tahun 1992. Menurut Bank Dunia, governance adalah "the manner in which power is exercised in the management of a country's social and economic resources for development", sedangkan $\mathrm{ADB}$, yang memiliki policy paper sejak tahun 1995 dengan tajuk Governance: Sound Development Management, mengartikulasikan empat elemen esensial dari good governance, yakni accountability, participation, predictability, dan transparancy. Sementara menurut UNDP, governance meliputi pemerintah, sektor swasta, dan civil society serta interaksi antarketiga elemen tersebut. Lebih lanjut, UNDP membuat ciri-ciri good 
governance yang meliputi pengikutsertaan semua, transparansi dan bertanggung jawab, efektif dan adil, menjamin adanya supremasi hukum, dan menjamin bahwa prioritas-prioritas politik, sosial, dan ekonomi didasarkan pada konsensus masyarakat serta memperhatikan kepentingan mereka yang paling miskin dan lemah dalam pengambilan keputusan menyangkut alokasi sumber daya pembangunan (lihat Sumarto, 2003: 3).

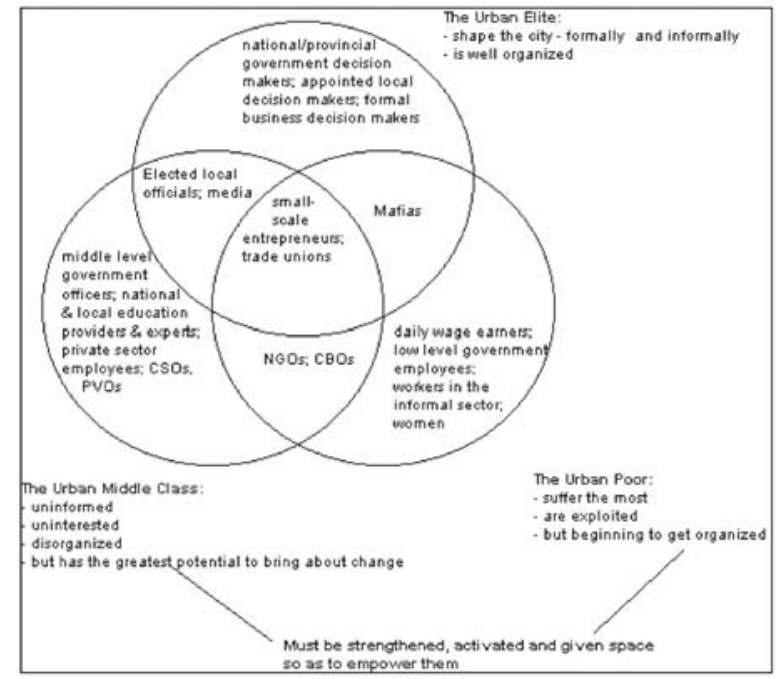

Gambar 1: Aktor-aktor masyarakat urban yang terlibat dalam good governance. Bagan ini di-down load dari http://www.unescap.org/huset/gg/ governance.htm.

Governance itu sendiri diartikan sebagai mekanisme, praktik, dan tata cara pemerintah dan warga dalam mengatur sumber daya serta memecahkan masalahmasalah publik. Dalam konsep ini, pemerintah hanya menjadi salah satu aktor dan tidak menjadi satusatunya aktor paling menentukan. Implikasinya, peran pemerintah sebagai pembangun maupun sebagai penyedia jasa pelayanan dan infrastruktur akan bergeser menjadi badan pendorong terciptanya lingkungan yang mampu memfasilitasi pihak lain di komunitas dan sektor swasta untuk ikut aktif melayani sektor tersebut. Definisi yang lain menyebutkan bahwa governance merupakan proses pembuatan keputusan dan melalui mana keputusan tersebut dilaksanakan atau tidak dilaksanakan (governance means the process of decision making and the process by which decisions are implemented or not implemented) (www. unescap.org). Oleh karena merupakan proses pembuatan keputusan, governance melibatkan banyak aktor sebagaimana terlihat dalam gambar 1 .

Dalam konsep governance paling dasar, terdapat tiga stakeholders utama yang saling berinteraksi, yakni negara atau pemerintah (state), dunia usaha atau pihak swasta (private sector), dan masyarakat (society). Dalam kaitan ini, terdapat tiga elemen essensial dalam good governance, yakni: Pertama, adanya kapasitas dalam pemerintahan untuk membuat kebijakan yang tepat serta adanya administrasi publik yang efisien dan accountable untuk menjalankannya. Kedua, demokratisasi dan pembangunan partisipatoris dengan mendorong keterlibatan yang lebih besar dari semua stakeholders. Ketiga, penghargaan terhadap hak asasi manusia dan penegakan hukum (Sumarto, 2003: 55 . 56).

Berdasarkan uraian di atas maka dapat ditarik benang merah bahwa governance adalah persoalan pengaturan. Menyangkut bagaimana mengelola sumber-sumber sosial dan ekonomi sebagai cara atau upaya untuk melakukan pembangunan, sedangkan good governance lebih merujuk pada bagaimana agar sumbersumber tersebut dapat dikelola secara baik atau efisien. Untuk itu, diperlukan akuntabilitas, partisipasi, prediktabilitas, aturan hukum, dan transparansi (lihat gambar 2). Dengan kata lain, good governance melibatkan usaha-usaha untuk membangun sistem penyelenggaraan pembangunan yang lebih demokratis.

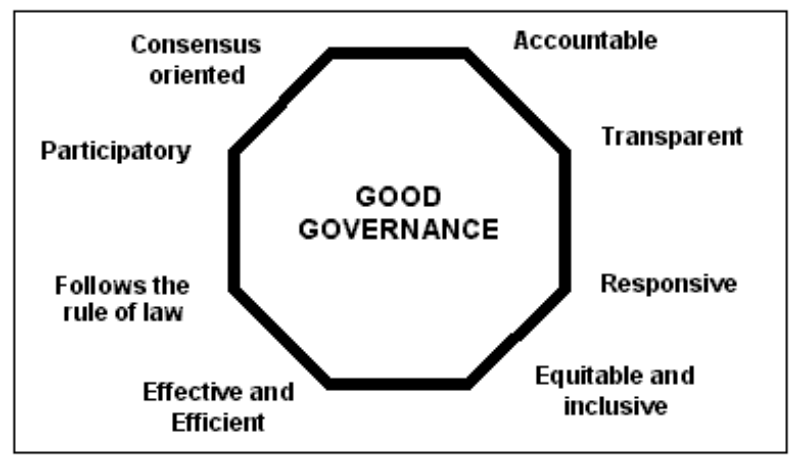

Gambar 2. Kharakteristik good governance. 
Kemudian, jika dilihat dari konteks kemunculannya, Abrahamsen menegaskan bahwa konstruksi Bank Dunia tentang good governance dimulai dari penolakannya terhadap kegagalan pembangunan masa lalu. Hal ini berarti bahwa agenda good governance pada dasarnya merupakan hasil koreksi terhadap kelemahan-kelemahan strategi pembangunan yang dilakukan pada masa sebelumnya. Seperti dikemukakan oleh Bank Dunia, upaya-upaya pembangunan pasca-kemerdekaan gagal karena strateginya salah. Dengan kata lain, kegagalan pembangunan pada masa lalu adalah ketiadaan pemerintahan yang baik (good governance). Oleh karena itu, konsep good governance yang ditawarkan oleh World Bank merupakan alternatif bagi usaha-usaha untuk mengoreksi strategi pembangunan yang gagal tersebut. Tentunya, ini juga merupakan koreksi terhadap karakter birokrasi pemerintahan yang berlaku di negara-negara Dunia Ketiga pada waktu itu. Sulit dipungkiri bahwa birokrasi di negara-negara Dunia Ketiga merupakan birokrasi yang korup dan tidak efisien. Salah satu penyebabnya, kuatnya birokrasi pemerintahan sebagai akibat lemahnya masyarakat sipil. Dalam konteks ini, negara secara sadar melemahkan masyarakat melalui berbagai cara. Intinya, negara otoritarian sebagaimana dikontestasikan oleh pemerintahan Orde Baru dan negara-negara Dunia Ketiga lainnya dengan struktur birokrasi yang kuat dan hampir-hampir tidak tersentuh merupakan bad governance dan menjadi penghalang bagi suatu pembangunan yang berhasil.

\section{KONTEKS GLOBAL KEMUNCULAN GOOD GOVERNANCE}

Jika dilihat dalam konteks yang lebih luas, maka kemunculan agenda good governance tidak saja dilatarbelakangi oleh kegagalan pembangunan masa lampau, tetapi juga harus dilihat dalam konteks kemenangan ideologis kelompok Kanan Baru (the new right) di Inggris dan Amerika Serikat pada periode tahun 1970-an. Kemenangan kelompok Kanan Baru ini menandai dimulainya tata ekonomi dunia yang jauh lebih liberal dibandingkan dengan proteksionisme. Berjalin dengan kemajuan atau revolusi di bidang teknologi komunikasi dan semakin rendahnya biaya transportasi telah mendorong liberalisasi dan globalisasi ekonomi dunia berlangsung dalam skala yang lebih luas dibandingkan sebelumnya.

Salah satu ajaran kelompok ini dapat dianggap paling meyakinkan dan diamini oleh lembaga-lembaga governance global (WTO, IMF, dan World Bank) dan sebagian besar para pengambil kebijakan publik, baik di negara-negara maju maupun di negara-negara berkembang adalah keyakinan yang sangat kuat terhadap kedaulatan pasar dan marginalisasi peran negara. Biasanya, para pemikir yang berada dalam garis ini sering disebut sebagai kaum hiperglobalis (David Held at. all, 1999). Ciri utama pandangan ini adalah sikap optimistik mereka dalam melihat globalisasi dan pengagungan yang berlebihan terhadap pasar.

Sementara pada waktu bersamaan, mereka 'menghujat' habis-habisan peran negara.

Menurut cara pandang kelompok ini, globalisasi didefinisikan sebagai sejarah baru kehidupan manusia di mana "negara tradisional telah menjadi tidak lagi relevan, lebih-lebih menjadi tidak mungkin dalam unit-unit bisnis dalam sebuah ekonomi global. Dalam pandangan kaum hiperglobalis, globalisasi ekonomi membawa serta gejala "denasionalisasi" ekonomi melalui pendirian jaringan-jaringan produksi transnasional (transnational networks of production), perdagangan dan keuangan. Dalam lingkungan ekonomi yang tanpa batas ini (economics borderless), pemerintahan nasional tidak lebih dari sekedar transmission belts bagi kapital global, atau secara lebih singkat sebagai institusi perantara yang menyisip diantara kekuatan lokal dan regional yang sedang tumbuh, serta mekanisme pengaturan global. Lebih lanjut, kelompok ini mempunyai keyakinan bahwa globalisasi ekonomi tengah membangun bentukbentuk baru organisasi sosial yang tengah menggantikan atau yang akhirnya akan menggantikan negara bangsa sebagai lembaga ekonomi utama dan unit politik dari masyarakat dunia.

Kenichi Ohmae (1995: 3) sebagai salah seorang pendukung tesis ekstrim globalisasi mengatakan bahwa dalam pasar dunia yang semakin kompetitif sekarang 
ini negara-negara bangsa (nation-states) tidak lagi mempunyai sumber-sumber yang tanpa batas yang dapat dimanfaatkan secara bebas untuk mendukung mewujudkan ambisi mereka. Dalam dunia baru, yaitu "dunia tanpa batas" (a world without borders), demikian Ohmae mengatakan, negara-negara bangsa dan penguasaan terhadap militer tidak lagi memainkan peran penting. Bahkan, peran mereka semakin memudar, dan secara meyakinkan akan segera digantikan oleh peran penting yang semakin meningkat oleh aktor-aktor nonteritorial, seperti perusahaanperusahaan multinasional, gerakan-gerakan transnasional, dan organisasi-organisasi internasional (Keohane dan Nye, 1977: 3).

Singkatnya, sebuah pergeseran yang besar tengah terjadi dari state-dominated ke arah market-dominated ekonomi internasional. Kelumpuhan ekonomi terpimpin Uni Soviet, kegagalan strategi substitusi impor negara-negara Dunia Ketiga, dan keberhasilan ekonomi Amerika Serikat pada era tahun 1990-an telah mendorong penerimaan unristricted market sebagai solusi bagi penyakit ekonomi modern. Karena deregulasi dan beberapa reformasi yang lain telah mengurangi peran negara dalam ekonomi, banyak orang mempunyai keyakinan bahwa pasar akan menjadi mekanisme paling penting dalam menentukan ekonomi domestik maupun internasional, dan terlebih lagi hubungan-hubungan politik. Dalam suatu ekonomi global yang sudah sangat terintegrasi, negara bangsa, menurut intepretasi ini, akan menjadi anakronisme dan berada dalam situasi kemunduran. Banyak dari mereka percaya bahwa menurunnya peran negara bangsa akan menjadi pembuka ke arah ekonomi global yang sesungguhnya, yang dicirikan oleh ketiadaan hambatan dalam perdagangan, aliran uang dalam skala global, dan kegiatan internasional dari perusahaan-perusahaan multinasional (Gilpin, 2001: 8; Strange, 2000).

Selaras dengan hal ini, globalisasi pada dasarnya juga dapat dimaknai sebagai sebuah preskripsi. Ini berarti bahwa globalisasi meliputi liberalisasi pasar global dan pasar nasional dengan asumsi bahwa arus perdagangan bebas, modal, dan informasi akan menciptakan hasil yang terbaik bagi pertumbuhan dan kemakmuran manusia (Petras dan Veltmeyer, 2003: 8).

Pandangan yang sangat optimistik ini telah menjadi sumber inspirasi bagi para pengambil kebijakan publik di negara-negara Dunia Ketiga, seperti di Meksiko (Heredia dan Purcel, 2003), Brazil, Argentina (Petras dan Veltmeyer, 2002), Chile (Steven Kangas, 2003), dan terlebih di lembaga-lembaga-lembaga governance global seperti World Trade Organization (WTO), International Monetary Fund (IMF), dan Bank Dunia (Stiglitz, 2002). Para pengambil kebijakan di negara-negara yang disebutkan tadi, entah secara sukarela atau melalui "paksaan" telah menyandarkan kebijakan ekonomi domestiknya pada keunggulan pasar, dan secara terus menerus meminggirkan peran negara dalam kehidupan ekonomi. Akibatnya, negara tidak lagi mempunyai peran yang signifikan dalam mempengaruhi ekonomi nasional. Suatu kondisi yang menciptakan persoalan lain dalam negara masing-masing.

Sementara itu, lembaga-lembaga global (IMF, WTO, dan Bank Dunia) juga mempunyai peran yang semakin penting dalam kaitannya dengan kemampuannya untuk mendeterminasi negara-negara Dunia Ketiga. WTO mempunyai peran yang signifikan bahkan paling berkuasa dalam menjamin terselenggaranya liberalisasi ekonomi (Jhamtani, 2000). IMF menyediakan utang bagi negara-negara debitur dengan persyaratan ketat yang memungkinkan IMF melakukan restrukturisasi ekonomi. Sementara itu, Structural Adjustment Bank Dunia juga menggunakan panduan yang serupa, dan mendorong kecenderungan yang sama dalam mensubordinasikan kebijakan domestik, terutama kebijakan yang berhubungan dengan proteksi dan subsidi. Keduanya lazim disebut sebagai Konsensus Washington. Konsensus ini menekankan liberalisasi pasar, privatisasi BUMN, dan kebijakan lain yang dirancang untuk mendorong investasi asing, termasuk dalam hal ini devaluasi dan deregulasi (Tabb, 2002: 76).

Pertanyaan selanjutnya adalah bagaimana hubungan antara kemenangan Kelompok Kanan Baru, globalisasi ekonomi, dan agenda good governance yang diprakarsai oleh Bank Dunia. Menurut penulis, terdapat 
hubungan yang erat dan saling terkait antara ketiganya, dan hubungan tersebut lebih daripada dominasi wacana. Namun, hubungan-hubungan itu juga melibatkan interaksi ideologis dari para pengambil kebijakan di lembaga-lembaga global tersebut dengan kemunculan ideologi pasar bebas, demokratisasi politik, dan munculnya perusahaan-perusahaan multinasional sebagai kekuatan dominan di era globalisasi ekonomi sekarang ini.

Orang-orang yang berada di lembaga-lembaga governance global saat ini seperti IMF, WTO, dan Bank Dunia didominasi oleh para pemikir neoliberal. Oleh karena itu, agenda mereka yang penting adalah bagaimana meliberalisasi sistem ekonomi dan politik negara-negara di dunia.. Ini dilakukan untuk menjamin dilaksanakannya kebijakan perdagangan bebas yang diyakini merupakan alat yang paling efektif untuk meraih kemakmuran dan perdamaian dunia. Dalam konteks ini, David Korten menegaskan bahwa para pendukung globalisasi ekonomi, dalam berbagai bentuknya, mempunyai keyakinan bahwa globalisasi ekonomi dan pasar bebas akan mendorong demokrasi dalam skala luas. Oleh karenanya, pembicaraan politik tentang pasar bebas dan perdagangan bebas adalah pesan gigih yang menegaskan bahwa kemajuan pasar bebas adalah kemajuan demokrasi (Korten, 1997: 108).

Dalam kaitan ini, perekonomian bebas dianggap sangat penting bagi masyarakat sipil, dan fokusnya adalah penciptaan "lingkungan yang memungkinkan" yang dapat "memunculkan kekuatan-kekuatan swasta serta mendorong prakarsa di semua tingkat.

Selanjutnya, perusahaan swasta dianggap sebagai komponen masyarakat sipil yang penting, secara aktif bertindak sebagai pendukung kehidupan masyarakat sipil. Oleh karena itu, tindakan-tindakan yang dilakukan untuk membantu kegiatan sektor swasta, termasuk usaha untuk memprivatisasi perusahaan negara adalah untuk memperkuat masyarakat sipil (Landel-Mills, 1992; dalam Abrahamsen, 2004: 102).

Dengan demikian, menjadi jelas bahwa kemunculan agenda good governance yang diperkenalkan oleh Bank Dunia pada tahun 1992 tidak bisa dilepaskan dari proyek demokratiasasi politik sebagai usaha untuk menciptakan iklim yang kondusif bagi berkembangnya kapital swasta. Ini menjadi jelas jika konsep good governance sebagaimana dipaparkan di atas kembali dirujuk. Dalam konsep good governance, setidaknya terdapat tiga stakeholders yang saling berinteraksi, yakni pemerintah atau negara, swasta, dan masyarakat. Dengan demikian, logika di balik munculnya konsep good governance adalah jelas. Neoliberalisme menghendaki kemajuan pasar bebas dan kemunduran peran negara dalam kegiatan ekonomi, dan globalisasi ekonomi sebagaimana sering dipromosikan oleh lembaga-lembaga governance global, pada akhirnya menempatkan swasta pada posisi sentral. Ketika negara telah sedemikian rupa dimarginalkan melalui berbagai regulasi dan proyek privatisasi BUMN yang diprakarsai oleh IMF dan Bank Dunia, aktor utama good governance pada akhirnya adalah jelas, yakni swasta. Dengan kata lain, proyek good governance yang dipromosikan oleh Bank Dunia di negara-negara Dunia Ketiga ditujukan untuk mendorong proses demokratisasi yang pada akhirnya memberi peran yang lebih besar pada swasta.

Dengan demikian, agenda good governance tidak hanya dapat dipandang sebagai transformasi diskursif yang, sembari menyatakan akan membebaskan rakyat miskin, memungkinkan untuk melangsungkan hegemoninya terhadap negara-negara Dunia Ketiga sebagaimana dikemukakan oleh Abrahamsen, tetapi dapat juga dilihat dari bagaimana lembaga-lembaga global ini berusaha untuk memperkuat peran swasta dalam kegiatan ekonomi global. Dalam konteks ini, Tabb (2003: 80; lihat juga Scholte, 2000) menegaskan bahwa keliru jika memandang negara tidak berdaya dalam ekonomi global, tetapi sesungguhnya yang terjadi adalah kekuasaan negara telah secara sadar dilihat sedemikian rupa untuk mengabdi pada kepentingan korporasi (swasta), bukan kepentingan warga negara. Dalam proses ini, paham demokrasi sosial gaya Keynesianisme nasional, yang dominan sejak Perang Dunia Kedua, digusur oleh neoliberalisme global. Lembaga-lembaga governance global inilah yang pada dasarnya membuat negara nasional mengabdi kepada kepentingan korporasi sehingga lebih tepat dikatakan bahwa negara di era gobal sekarang ini 
adalah negara serba diatur di mana pasar dijauhkan dari campur tangan politik, tetapi keberhasilan sistem kekebalan pasar ini bergantung pada pemahaman bahwa jika tatanan pasar dikehendaki berjalan lancar maka diperlukan adanya lembaga-lembaga pengatur (regulatory institutions) yang kuat (Jayasuriya, 2000: 42), dan nampaknya WTO, IMF, dan Bank Dunia telah mampu menjalankan peran tersebut dengan sangat baik (Stiglitz, 2002).

\section{APA YANG SALAH?}

Wacana pembangunan telah mendominasi para intelektual dan para pengambil kebijakan publik di negara-negara Dunia Ketiga sejak tahun 1950-an dan tahun 1960-an. Dalam konteks Indonesia, pembangunan secara intensif telah dipraktikkan oleh pemerintahan Orde Baru melalui Repelita sejak tahun 1969. Dengan dukungan militer yang kuat, dapat dianggap teknokrat lulusan universitas Barat, yang lebih sering dikenal sebagai 'Mafia Berkeley', sebagai arsitek pembangunan Indonesia para era tersebut. Dalam perspektif Gramscian, ini dapat dianggap sebagai bentuk hegemoni Barat (tepatnya AS) terhadap negara Dunia Ketiga (dalam kasus ini, Indonesia). Kemudian, globalisasi ekonomi direspon oleh pemerintahan Orde Baru melalui paket-paket deregulasi sejak tahun 1980-an. Kebijakan ini telah mendorong struktur ekonomi Indonesia menjadi lebih terbuka terhadap investasi asing, dan pada tataran tertentu telah mendorong industrialisasi di Indonesia.

Namun, berbagai upaya pembangunan tersebut dapat dikatakan kurang berhasil jika tidak mau dikatakan gagal. Hal ini karena hasil-hasil pembangunan hanya dinikmati oleh segelintir elit (ekonomi ataupun politik), dan Indonesia masih tidak beranjak dari kategori negara Dunia Ketiga yang tingkat kemiskinannya masih tinggi.

Ada banyak teori yang dapat digunakan untuk menjelaskan kegagalan pembangunan tersebut. Bagi para pemikir yang berpijak pada tradisi Marxian atau Neo-marxian, kegagalan pembangunan adalah akibat kendala struktural. Negara-negara Dunia Ketiga sulit untuk dapat mengejar ketertinggalannya dengan negara- negara Barat karena memang struktur ekonomi politik internasional menghalangi negara-negara tersebut untuk berkembang menjadi negara industri maju. Sementara di sisi yang lain, para pendukung kebijakan developmentalisme melihat bahwa kegagalan pembangunan adalah, seperti telah disinggung di awal, karena tiadanya pemerintahan yang baik. Oleh karena itu, persoalannya adalah bagaimana membentuk pemerintahan yang baik berdasarkan prinsip-prinsip good governance.

Dengan demikian, munculnya konsep good governance yang belakangan menjadi isu sentral di kalangan akademisi, para pengambil kebijakan publik, media, dan elemen masyarakat sipil yang lain nampaknya juga terjebak ke dalam pemahaman ini. Dalam konteks Indonesia, pemahaman seperti ini adalah relevan berdasarkan beberapa alasan. Pertama, birokrasi pemerintah yang direpresentasikan oleh Orde Baru adalah suatu birokrasi patrimonial yang korup, nepotis, dan penuh aroma kolusi (KKN). Kedua, pembangunan ekonomi yang bertumpu pada pinjaman luar negeri dan mengejar tingkat pertumbuhan ekonomi yang tinggi tidak diiringi dengan pembangunan politik yang demokratis. Sebaliknya, pembangunan tersebut telah 'memapankan' rejim politik otoriter yang menegaskan konsensus politik yang bersifat elitis dan partisipasi masyarakat dimarginalkan. Sementara dalam waktu bersamaan, birokrasi pemerintah mempunyai tingkat akuntabilitas yang rendah. Singkatnya, pemerintahan Orde Baru dapat dikategorikan sebagai bad governance karena ketiadaan transparansi, akuntabilitas, partisipasi, dan responsibilitas. Oleh karena itu, ketika gerakan reformasi berhasil menumbangkan rejim yang dikenal korup dan menindas tersebut, serta merta agenda good governance menempati posisi sentral dalam diskusi-diskusi publik. Seolah-olah, konsep good governance dianggap menjadi 'resep mujarab' bagi kegagalan pembangunan yang dilaksanakan selama pemerintahan Orde Baru.

Namun, dengan merujuk pada para pemikir kritis seperti sedikit telah dipaparkan sebelumnya, betapapun baiknya konsep tersebut dalam 
menjanjikan kebaikan pemerintahan dan demokrasi hendaknya ia tetap dilihat secara kritis. Oleh karena itu, kritik yang menyatakan bahwa wacana good governance sebagai kelanjutan dari wacana pembangunan yang telah mendominasi Dunia Ketiga pada era sebelumnya dapat dikatakan sebagai bagian dari proyek global "produksi hegemoni" atau usaha serius kekuatan-kekuatan dominan di negara-negara maju untuk membentuk sebuah blok historis skala dunia masih tetap relevan. Dengan demikian, muatan ideologis dan ide-ide atau teori yang membentuk wacana itu tidak bisa dikatakan sebagai "obyektif". Menurut cara pandang ini, teori selalu mendukung tujuan seseorang atau mendukung berbagai tujuan. Dengan kata lain, semua teori mempunyai sebuah perspektif (Robert Cox, 1995; dalam Sugiono, 1999: 56).

Oleh karena itu, tulisan ini akan berusaha melanjutkan kritik tersebut pada level yang lebih luas, yakni pada tataran konseptual dan implikasi yang mungkin ditimbulkan akibat diimplementasikannya good governance. Kritik pertama yang dapat diajukan adalah menyangkut netralitas konsep good governance. Pada dasarnya, konsep ini bukanlah merupakan konsep yang netral. Pertama kali, konsep ini dimunculkan oleh Bank Dunia (Abrahamsen, 2000; Sumarto 2002) sebagai reaksi atas kegagalan pembangunan masa lampau. Jika kita sepakat bahwa ide-ide dan teori tidak bisa bersifat obyektif dan karenanya ia selalu mengandung perspektif tertentu, maka menjadi jelas perspektif siapakah yang coba direpresentasikan oleh pemunculan ide atau teori tersebut, yakni para pendukung pasar bebas atau yang sering disebut sebagai kaum neoliberal. Telah menjadi rahasia umum bahwa lembaga-lembaga global seperti WTO, IMF, dan World Bank, didominasi oleh para pendukung neoliberalisme ekonomi yang menolak campur tangan negara, sementara di waktu bersamaan mengagungkan kebajikan pasar. Terlepas bahwa pandangan-pandangan kaum neoliberal dianggap gagal dalam mewujudkan pembangunan ekonomi yang berkeadilan sosial, dan mempunyai relevansi yang sangat rendah pada tataran empiris. Dalam konteks ini, kritik Joseph Stiglitz relevan untuk dikemukakan. Menurut Stiglitz (2002:
92, keberhasilan pembangunan di negara-negara Asia Timur yang termasuk ke dalam Negara Industri Baru (NICs) adalah karena kebijakan yang bersifat gradual dalam meliberalisasi perdagangan dan sektor finansial. Ini bertentangan dengan yang direkomendasikan oleh Konsensus Washington sebagaimana dianut oleh lembaga-lembaga global tersebut yang menekankan liberalisasi sektor keuangan dan perdagangan dengan cepat tanpa kontrol negara. Malahan, negara yang melakukan rekomendasi Konsensus Washington ini terbukti gagal dalam melakukan reformasi ekonomi dan politik, dan kini tengah menghadapi masa depan ekonomi dan politik yang tidak pasti seperti yang terjadi di bekas negara Uni Soviet.

Di negara-negara Amerika Latin dan Afrika, liberalisasi dan privatisasi, sebagaimana direkomendasikan oleh Bank Dunia dan IMF, pada akhirnya lebih menguntungkan perusahaan-perusahaan transnasional dibandingkan dengan masyarakat domestik negara yang bersangkutan. Dalam konteks ini, persoalan yang muncul adalah kepentingan siapa yang direpresentasikan, dan jawabannya adalah kepentingan perusahaan-perusahaan transnasional. Rekomendasi kebijakan yang diberikan baik Bank Dunia, maupun IMF pada dasarnya ditujukan untuk mengakomodasi kepentingan perusahaan-perusahaan transnasional atau secara lebih spesifik perusahaan transnasional Amerika Serikat (Tabb, 2002; Korten, 2002; dan Stiglizt, 2002). Oleh karena itu, kemunculan konsep good governance yang diprakarsai oleh Bank Dunia hendaknya juga dilihat dalam konteks ini. Ini bukan suatu pola pikiran yang picik, tetapi lebih merupakan suatu cara berfikir yang lebih hati-hati sebagai upaya untuk menjaga tetap tegaknya demokrasi dan keadilan sosial. Singkatnya, kelahiran konsep good governance hendaknya dilihat tidak hanya sebagai respon atas kegagalan pembangunan masa lampau karena ketiadaan pemerintahan yang baik, tetapi juga harus dilihat dalam konteks ideologi yang 'bermain' di balik kemunculan konsep tersebut, yakni globalisasi dan liberalisasi ekonomi yang lebih mengabdi kepada kepentingan korporasi global

Kedua, asumsi yang dibangun di balik konsep good 
governance adalah adanya interaksi yang seimbang antara pemerintah, swasta, dan masyarakat seperti terlihat dalam gambar sebelumnya. Namun, di era globalisasi ekonomi sekarang ini di mana negara telah dimarginalkan sedemikian rupa dalam melayani kepentingan publik, dan perusahaan-perusahaan multinasional mempunyai kekuatan yang tidak ada bandingnya, apakah masih mungkin membentuk suatu interaksi yang seimbang. Berbagai tulisan yang muncul belakangan menyebutkan bagaimana demokrasi yang menjadi salah satu landasan diberlakukannya good governance telah digerogoti sedemikian rupa oleh perusahaan-perusahaan multinasional melalui aturan yang direkomendasikan oleh lembaga-lembaga governance global, seperti IMF, WTO, dan Bank Dunia. Dalam hal ini, suatu kritik yang cukup tajam dikemukakan oleh David Korten ke dalam hampir keseluruhan buku yang ditulisnya, the Post Corporate World: Life After Capitalism (2002). Ia menyatakan bahwa kekuasaan ekonomi saat ini telah merepresentasikan dirinya menjadi kekuasaan politik, dan pemerintahan nasional kini lebih mengabdi kepada kepentingan korporasi global dibandingkan dengan kepentingan warga negara.

Dengan demikian, jika liberalisasi ekonomi dan perdagangan bebas dapat dianggap sebagai proyek kaum neoliberal yang lebih bersifat ekonomi sebagai upaya untuk melakukan akumulasi kekayaan melalui lembaga-lembaga transnasional tadi, maka "demokrasi" menjadi proyek politik mereka. Hal ini dapat disaksikan dari berbagai proyek liberalisasi ekonomi dan perdagangan yang juga diikuti oleh proyek-proyek demokratisasi politik di negara yang bersangkutan. Namun, hal ini hendaknya juga dilihat secara kritis. Seperti pernah ditegaskan oleh William K. Tabb dan Noam Chomsky, proyek demokratisasi pada intinya adalah sebuah bualan belaka. Menurut kedua penulis ini, proyek demokratisasi harus dilihat dalam kaca mata kepentingan negara dominan, dalam hal ini Amerika Serikat. Bagi negara-negara maju, sistem politik otoriter dan proteksionis hampir dapat dipastikan menjadi penghalang utama masuknya investasi perusahaan-perusahaan multinasional negara- negara maju. Jika hal ini dibiarkan, maka akan menghalangi perusahaan-perusahaan multinasional untuk meraih keuntungan maksimal dari berbagai sumber daya yang mungkin ditawarkan oleh negara tersebut, sementara dilihat dari perspektif politik, hal ini akan menyulitkan negara-negara besar untuk melakukan semacam "infiltrasi" politik ke negaranegara Dunia Ketiga. Oleh karena itu, untuk menjamin investasi perusahaan transnasional bisa masuk, dan negara-negara maju dapat melakukan kontrol terhadap negara-negara Dunia Ketiga maka demokrasi menjadi agenda reformasi berikutnya.

Akhirnya, sulit untuk mengatakan bahwa interaksi yang seimbang antara aktor-aktor dalam governance akan terjadi mengingat kekuasaan ekonomi perusahaan multinasional telah menjadi kekuasaan politik yang menghambat demokrasi. Dengan demikian, kita dapat mengatakan bahwa kemunculan agenda good governance dapat dianggap sebagai proyek demokratisasi politik yang berujung pada penguasaan aktor-aktor ekonomi global terhadap sumber daya ekonomi nasional. Sebaliknya, agenda good governance hanya akan menjadi proyek politis yang menguntungkan korporasikorporasi global yang kekuatannya sekarang mengalahkan kemampuan banyak negara Dunia Ketiga. Pada akhir abad 20 saja, mereka berhasil menguasai $67 \%$ dari perdagangan antarmereka sendiri, dan 34,1\% dari perdagangan dunia. Sementara di bidang investasi, mereka menguasai sekitar 75\% dari total investasi global (Fakih, 2000).

\section{KESIMPULAN}

Sebagai catatan penutup, ada beberapa hal yang perlu dikemukakan kembali dan mungkin layak mendapatkan perhatian dari para pengambil kebijakan publik, para akademisi, dan komponen masyarakat sipil yang lain. Pertama, apakah agenda good governance ini akan kita tolak ataukah diterima dengan suatu catatan. Saya lebih cenderung untuk menerima dengan suatu catatan. Persoalan utama dari konsep good governance yang diprakarsai oleh Bank Dunia ini adalah besarnya peran swasta dalam proses pengaturan kebijakan publik. Akibatnya, pemerintah hanya akan 
menjadi penyedia regulasi yang menguntungkan kepentingan korporasi-korporasi global sebagaimana dimaksudkan awalnya. Oleh karena itu, hendaknya terdapat regulasi yang menjamin pemerintah untuk melindungi kepentingan masyarakat di luar korporasi global.

Berbagai pengalaman yang ditunjukkan oleh negaranegara Industri Baru menegaskan bahwa keberhasilan industrialisasi karena ditopang oleh peran negara yang sangat kuat dalam "memberi arah" industrialisasi. Model industri di Taiwan, Korea Selatan, dan Hongkong lebih sesuai dengan model state-led development dibandingkan dengan market-driven development. Tidak selamanya kepentingan korporasi global sesuai dengan kepentingan masyarakat sehingga tidak semua urusan yang berkaitan dengan hajat hidup orang banyak dapat diserahkan kepada swasta. Oleh karena itu, good governance hendaknya tetap menjamin demokrasi dalam arti sebenarnya dengan mengembalikan dan menghormati hak-hak individu, dan hendaknya pemerintah tetap memainkan peran yang signifikan tidak hanya dalam mengurangi kegagalan pasar (mitigating market failure), tetapi juga dalam mendorong keadilan sosial (social justice) (Stiglitz, 2002: 218). Pasar mempunyai kemungkinan untuk tidak melayani masyarakat yang tidak mempunyai sumber-sumber yang cukup mengingat pasar mempunyai hukumnya sendiri berdasarkan prinsip supply and demand. Oleh karena itu, pemerintah dalam prinsip good governance harus tetap menjamin tersedianya pelayanan yang cukup bagi masyarakat miskin yang besar kemungkinan tidak akan dilayani oleh pasar. Di negara-negara Asia Timur, Amerika Serikat, dan negara-negara yang paling berhasil, pemerintah (goverment) memainkan peran yang signifikan dalam menyediakan infrastruktur, pendidikan yang berkualitas, dan jaring pengaman sosial bagi masyarakat miskin.

Kedua, pendefinisian kembali demokrasi sebagai penopang good governance. Tipe ideal good governance mempunyai delapan karakteristik pokok, yakni participatory, consensus oriented, accountable, transparent, responsive, effective and efficient, equitable and inclusive and follows the rule of law (www.unescap.org). Hal ini dimaksudkan untuk menjamin pengurangan korupsi dan adanya jaminan bahwa suara-suara minoritas dan terpinggirkan diperhatikan dalam proses perumusan kebijakan publik. Selain tentunya untuk menjamin akuntabilitas publik. Ini mengandaikan adanya masyarakat sipil (civil society) yang kuat di mana komponen-komponennya tidak ada yang saling mendominasi satu dengan yang lain. Pada masa lampau, ancaman masyarakat sipil adalah negara, tetapi di era global sekarang ini ancaman terhadap masyarakat sipil tidak hanya berasal dari negara, tetapi juga korporasi-korporasi global dan lembaga-lembaga global yang hampir tidak mempunyai akuntabilitas sama sekali terhadap masyarakat. Oleh karena itu, agenda good governance hendaknya tidak hanya dilaksanakan di lembaga-lembaga publik seperti pemerintah, tetapi hendaknya juga diberlakukan pada korporasi (corporate governance), lembaga-lembaga governance global, dan bahkan Lembaga Swadaya Masyarakat. Kematian demokrasi (the death of democracy) adalah akibat semakin berkuasanya korporasi-korporasi global mengungguli negara bangsa. Oleh karena itu, tugas negara selain mendapatkan kembali kontrolnya dalam ekonomi politik domestik adalah mengembalikan hakhak individu dan tidak memberikannya kepada korporasi-korporasi global yang cenderung monopolistik dan oligopolistik (Korten, 2002).

\section{CATATAN AKHIR}

Yang dimaksud dengan intelektual organik adalah setiap intelektual yang kehadirannya terkait dengan struktur produktif dan politik masyarakat, yakni dengan kelompok atau kelas yang mereka wakili. Dalam kalimat Gramsci, "setiap kelompok sosial, yang muncul di kawasan orisinal sebuah fungsi esensial di dunia produksi ekonomi, menciptakan bersama dirinya sendiri, secara organik, satu atau lebih strata intelektual yang memberikan homogenitas dan kesadaran fungsinya sendiri tidak hanya dalam bidang ekonomi, tetapi juga dalam bidang politik" (lihat Muhadi Sugiono, 1999: 43).

\section{REFERENSI}

Abrahamsen, Rita, 2000, Disciplining Democracy: Development Discourse and Good Governance in Africa, New York: Zed Book. Arief, Sritua, 1999, "Kejahatan Hutang Luar Negeri dan Reformasi Bank Dunia", Jurnal Wacana No III tahun 1999. 
Fakih, Mansour, 2000, "Pembangunan: Pelajaran Apa yang Kita Dapat" Jurnal Wacana, edisi 5 Tahun 2000.

Gilpin, Robert (2001), Global Political Economy: Understanding the Economic Order (Princeton University Press).

Held, David at. al., (1999), Global Transformation: Politics, Economics, and Culture, (Stanford: Standford University Press).

Heredia, Carlos dan Mary Purcell, 2003, "Penyesuaian Struktural di Meksiko: Akar Krisis", dalam William Robinson at. al., Hantu Neoliberalisme, Jakarta: C-Books.

Hirst, Paul and Grahame Thompson, 1996. Globalization in Question, Blackwell Publisher Ltd., Cambridge.

Jayasuriya, Kanishka, 2000, “Dari Kekuasaan Negara ke Kekuasaan pasar Global", Jurnal Wacana No. VII Tahun 2000.

Kangas, Steve, 2003, "The Chicago Boys dan "keajaiban Ekonomi Chile", dalam William Robinson at.al., Hantu neoliberalisme, Jakarta: CBooks.

Keohane, Roberth O. and Joseph S. Nye, 1977. Power and Interdepndence: World Politics in Transition, Little, Brown and Company Inc., Boston.

Korten, David. C, 1997, When Corporations Rule the World (Ketika Korporasi Menguasai Dunia), alih bahasa Agus Maulana, Jakarta: Professional Books.

2002, The Post Corporate World (Kehidupan

Setelah Kapitalisme), alih bahasa A. Rahman Zainuddin, Jakarta: Yayasan Obor.

Latif, Yudi dan Idi Subandy Ibrahim, 1996, “Bahasa dan Kekuasaan: Politik Wacana di Panggung Orde Baru", dalam Yudi Latif dan Idi Subandi Ibrahim, 1996, Bahasa dan Kekuasaan: Politik Wacana di Panggung Orde Baru (Jakarta: Mizan).

Ohmae, Kenichi (1995), "The End of Nation State," The 1995 Panglaykim Memorial Lecture, Jakarta, 4 Oktober.

Petras, James dan Henry Veltmeyer, 2002, Imperialisme Abad 21, Yogyakarta: Kreasi Wacana

Sayer, Andrew, 1995, Radical Political Economy: A Critique, Oxford UK \& Cambridge USA, Blackwell.

Scholte, Jan Art, 2000, Globalization: A Critical Introduction, New York: St. Martin Press.

Stiglitz, Joseph E, 2002, Globalization and Its Discontent, Allen Lane: Penguin Books.

Strange, Susan, 2000, "The Declining Authority of State", dalam David Held dan Anthony McGrew (ed.), The Global Transformations Reader: An Introduction to the Globalization Debate, Cambridge: Polity Press,

Sugiono, Muhadi, 1999. Kritik Antonio Gramsci Terhadap Pembangunan Dunia Ketiga, Pustaka Pelajar, Yogyakarta.

Sumarto, Hetifah Sj, 2003, Inovasi, Partisipasi, dan Good Governance, Jakarta: Yayasan Obor Indonesia.

Tabb, William K. (2003), Tabir Politik Globalisasi (Yogyakarta: Lafadl).

Artikel dari website

Chomsky, Noam, 1997, "Market Democracy in a Neoliberal Order: Doctrines and Reality", makalah download dari http:// www.zmag.org/chomsky/index.cfm.

"The Role of the IMF in Governance Issues: Guidance Note", Approved by the IMF Executive Board, July 25, 1997, artikel download from http://www.imf.org/external/pubs/ft/exrp/govern/ govindex.htm

"What is Good Governance?" artikel download from http:// www.unescap.org/huset/gg/governance.htm 